\title{
In situ thermal decomposition route: Preparation and characterization of nano nickel, cobalt, and copper oxides using an aromatic amine complexes as a low-cost simple precursor
}

\author{
Moamen S. Refat ${ }^{*}$, Soha F. Mohamed ${ }^{2}$, Tariq A. Altalhi ${ }^{1}$, Safyah B. Bakare ${ }^{3}$ \\ and Ghaferah H. Al-Hazmi ${ }^{4}$ \\ ${ }^{1}$ Department of Chemistry, College of Science, Taif University, P.O. Box 11099, Taif 21944, Saudi Arabia \\ ${ }^{2}$ Department of Chemistry, College of Science, Zagazig University, Zagazig, Egypt \\ ${ }^{3}$ Faculty of Education, Shaqra University, Al Muzahimiyah, Shaqra, Riyadh Province, P.O. Box 205, Zip Code 11972, \\ Kingdom Saudi Arabia \\ ${ }^{4}$ Department of Chemistry, College of Science, Princess Nourah bint Abdulrahman University, Riyadh 11671, KSA \\ "Corresponding author: e-mail: msrefat@yahoo.com \& moamen@tu.edu.sa
}

\begin{abstract}
The main interest now is the development of metallic or inorganic-organic compounds to prepare nanoparticle materials. The use of new compounds could be beneficial and open a new method for preparing nanomaterials to control the size, shape, and size of the nanocrystals. In this article, the thermal decomposition of $\left[\mathrm{M}_{2}(\mathrm{o}-\mathrm{tol})_{2}\left(\mathrm{H}_{2} \mathrm{O}\right)_{8}\right]$ $\mathrm{Cl}_{4}$ (where o-tol is ortho-tolidine compound, $\mathrm{M}=\mathrm{Ni}^{2+}, \mathrm{Co}^{2+}, \mathrm{Cu}^{2+}$ ) new precursor complex was discussed in solid-state conditions. The thermal decomposition route showed that the synthesized three complexes were easily decomposed into $\mathrm{NiO}, \mathrm{Co}_{3} \mathrm{O}_{4}$ and $\mathrm{CuO}$ nanoparticles. This decomposition was performed at low temperatures $\left(\sim 600^{\circ} \mathrm{C}\right)$ in atmospheric air without using any expensive and toxic solvent or complicated equipment. The obtained product was identified by Fourier transform infrared spectroscopy (FT-IR), X-ray diffraction (XRD), transmission electron microscopy (TEM) and energy-dispersive X-ray spectroscopy (EDX). FT-IR, XRD and EDX analyses revealed that the $\mathrm{NiO}$ nanoparticles exhibit a face-centered-cubic lattice structure with a crystallite size of 9-12 $\mathrm{nm}$. The formation of a highly pure spinel-type $\mathrm{Co}_{3} \mathrm{O}_{4}$ phase with cubic structure showed that the $\mathrm{Co}_{3} \mathrm{O}_{4}$ nanoparticles have a sphere-like morphology with an average size of 8-10 $\mathrm{nm}$. The XRD patterns of the $\mathrm{CuO}$ confirmed that the monoclinic phase with the average diameter of the spherical nanoparticles was approximately 9-15 nm.
\end{abstract}

Keywords: o-tolidine; $\mathrm{NiO}, \mathrm{Co}_{3} \mathrm{O}_{4}, \mathrm{CuO}, \mathrm{XRD}$, TEM, nanoparticles; complexation.

\section{INTRODUCTION}

Ortho-tolidine is an organic compound with the molecular formula $\left(\mathrm{CH}_{3}-\mathrm{C}_{6} \mathrm{H}_{4}-\mathrm{NH}_{2}\right)_{2}$. It is a colorless organic compound, slightly soluble in water, forms salts with acids, used mainly for dye production ${ }^{1}$, as intermediate to produce soluble azo dyes and insoluble textile pigments, leather, paper industries, and to produce certain elastomers. o-Tolidine was widely used as a reagent/indicator in analytical, clinical, and forensic chemistry, such as in the analytical determination of gold, or determination of the chlorine level in swimming pool water ${ }^{2}$.

Transition metal oxide nanoparticles represent an important class of inorganic nanomaterials that have been investigated extensively due to their interesting catalytic, electronic, and magnetic properties relative to those of the bulk counterparts, and the wide scope of their potential applications ${ }^{3}$. The nickel oxide nanoparticles $(\mathrm{NiO})$ are one of the supreme transition metal oxides, it has been a p-type semiconductor behavior. The different features of the $\mathrm{NiO}$ nanoparticles have prompted different research topics. The quantum size, high specific surface area, volume, and macroscopic quantum tunneling effects revealed the unique magnetic, electronic, catalytic, chemical, and optical properties of the $\mathrm{NiO}$ nanoparticles. These properties encouraged their extensive application in ultra-magnetic devices, photoelectric smart windows, photocatalytic applications, electrochemical supercapacitors, photoelectric devices, and gas sensors ${ }^{4-9}$. $\mathrm{NiO}$ nanoparticles are also magnetic nanoparticles with good electrochemical activity, which motivate their use in electrochemical biosensors ${ }^{8,9}$. Cobalt oxide $\left(\mathrm{Co}_{3} \mathrm{O}_{4}\right)$ with spinel-type as a semiconductor material having realizable applications in gas sensors ${ }^{10}$, heterogeneous catalysts ${ }^{11}$, electrochemical devices ${ }^{12}$, lithium-ion batteries $^{13}$, materials magnetism ${ }^{14,15}$ and photocatalysts ${ }^{16}$. In literature, increasing interest has been focused on the synthesis of $\mathrm{Co}_{3} \mathrm{O}_{4}$ nanostructures due to the influence of particle size on their properties and applications ${ }^{17}$. Various wet chemical methods such as hydrothermal/thermal solvent method $^{18}$, combustion method ${ }^{19}$, microwave heating ${ }^{20}$, gel solution process $^{21}$, spray pyrolysis ${ }^{22}$, sonochemical method ${ }^{23}$, co-sedimentation ${ }^{24}$, ionic liquid-assisted method ${ }^{25}$, a polyol method $^{26}$ and a non-aqueous method ${ }^{27}$ are reported for the assembly of $\mathrm{Co}_{3} \mathrm{O}_{4}$ nanostructures. However, most of these methods involve complex processes, high sintering temperatures, and expensive and toxic precursors. Additionally, they are either time-consuming or require expensive tools. Solid-state thermolysis of molecular precursors is the simplest and least expensive to preparing metal oxide nanostructures. This promising technology offers many unique advantages and significant advantages over other methods including easy work, relatively short reaction time, and preparation of numerous inorganic nanomaterials with unique sizes, specific shapes, and narrow size distribution ${ }^{28}$. The copper oxide $(\mathrm{CuO})$ has been studied as a p-type semiconductor material with a narrow band gap of $1.2 \mathrm{eV}$, because of its natural abundance of raw materials, low-cost production processing, non-toxic nature, and reasonably good electrical and optical properties. $\mathrm{CuO}$ nanoparticles have been of great interest due to their potential applications in a wide range of fields including electronic and optoelectronic devices, such as microelectromechanical systems, field-effect transistors, electrochemical cells, gas sensors, magnetic storage media, solar cells, and field emitters, and nanocatalysis devices. It has also been emphasized recently that regardless of size, the shape of the nanostructure is equally important 
for controlling various properties ${ }^{29}$. The main task of this work is to synthesis nanoparticles of $\mathrm{NiO}, \mathrm{Co}_{3} \mathrm{O}_{4}$, and $\mathrm{CuO}$ using the thermal decomposition method and its physicochemical characterizations.

This article is aimed to synthesis of three transition metal oxide nanoparticles from a simple precursor in a short time and with an easy, low temperature, low-cost method without using any special instrument. To the best of our knowledge, this is the first report on the synthesis of $\mathrm{NiO}, \mathrm{Co}_{3} \mathrm{O}_{4}$, and $\mathrm{CuO}$ nanoparticles from aromatic amine with $\left[\mathrm{M}_{2}(\mathrm{o} \text {-tol })_{2}\left(\mathrm{H}_{2} \mathrm{O}\right)_{8}\right] \mathrm{Cl}_{4}$ precursor complex.

\section{EXPERIMENTAL}

\section{Chemicals and Instrument Techniques}

All the chemicals $\left(\mathrm{NiCl}_{2} \cdot 6 \mathrm{H}_{2} \mathrm{O}, \mathrm{CoCl}_{2} \cdot 6 \mathrm{H}_{2} \mathrm{O}\right.$, $\mathrm{CuCl}_{2} \cdot 2 \mathrm{H}_{2} \mathrm{O}$, and ortho-tolidine) and the solvents (methanol) were purchased from Sigma-Aldrich Chemical Company and used without further purification. The FT-IR spectra were recorded in the range 4000-400 $\mathrm{cm}^{-1}$ on Bruker FTIR Spectrophotometer. The electronic spectra were recorded in the range $200-800 \mathrm{~nm}$ at room temperature in the solid-state using a UV2 Unicam UV/ Vis Spectrophotometer. Microanalyses (C, H and N) were recorded on a Perkin Elmer $2400 \mathrm{CHN}$ analyzer. Melting points of the compounds were determined in open capillaries in an electrical MPS10-120 melting point apparatus. The magnetic moments were determined on a Guoy balance and the diamagnetic corrections of the complexes were calculated using Pascal's constants. Molar conductivities were measured in DMSO solution at $10^{-3} \mathrm{M}$ concentration using a Jenway 4010 conductivity meter. The metal contents were estimated with a gravimetrical method at $800^{\circ} \mathrm{C}$ by converted the synthesized metal complexes to metal oxides as a stable form that suitable to calculate the percentage of metal ions. The $\mathrm{X}$-ray diffraction patterns were recorded on X 'Pert PRO PANanalytical X-ray powder diffraction, target copper with secondary monochromate. The transmission electron microscopy images (TEM) were performed using JEOL 100s microscopy.

\section{Synthesis of ortho-tolidine precursor complex and na- noparticle oxides}

The precursors $\left[\mathrm{M}_{2}(\mathrm{o}-\mathrm{tol})_{2}\left(\mathrm{H}_{2} \mathrm{O}\right)_{8}\right] \mathrm{Cl}_{4}$ (where o-tol is ortho-tolidine compound, $\mathrm{M}=\mathrm{Ni}^{2+}, \mathrm{Co}^{2+}, \mathrm{Cu}^{2+}$ ) were synthesized according to the briefly steps as follows, 4.25 grams of ortho-tolidine $(20 \mathrm{mmol})$ was dissolved in $20 \mathrm{~mL}$ of methanol, and $20 \mathrm{~mL}$ of water solution of $\mathrm{NiCl}_{2} \cdot 6 \mathrm{H}_{2} \mathrm{O}, \mathrm{CoCl}_{2} \cdot 6 \mathrm{H}_{2} \mathrm{O}$, or $\mathrm{CuCl}_{2} \cdot 2 \mathrm{H}_{2} \mathrm{O}(20$ mmol) was added with heating at $70^{\circ} \mathrm{C}$ and continuously stirring. The color precipitates of $\left[\mathrm{M}_{2}(\mathrm{o}-\mathrm{tol})_{2}\left(\mathrm{H}_{2} \mathrm{O}\right)_{8}\right] \mathrm{Cl}_{4}$, are collected on a paper filter, washed with methanol and ether, and then dried under vacuum over anhydrous calcium chloride. The composition of the complexes was confirmed by elemental analysis, electronic, magnetic, molar conductance, FT-IR, and thermal analyses. Anal. calc. for $\left[\mathrm{Ni}_{2}(\mathrm{o}-\mathrm{tol})_{2}\left(\mathrm{H}_{2} \mathrm{O}\right)_{8}\right] \mathrm{Cl}_{4}$ : C, 40.62; H, 5.84; N, 6.77; $\mathrm{Cl}, 17.13$; Ni, 14.18; found: C, 40.43; H, 5.82; N, 6.67; $\mathrm{Cl}, 17.08$; Ni, 14.01 , yield: $77 \%$. M.p. $325^{\circ} \mathrm{C}$. Anal. calc. for $\left[\mathrm{Co}_{2}(\mathrm{o}-\mathrm{tol})_{2}\left(\mathrm{H}_{2} \mathrm{O}\right)_{8}\right] \mathrm{Cl}_{4}: \mathrm{C}, 40.60 ; \mathrm{H}, 5.84 ; \mathrm{N}, 6.76$; $\mathrm{Cl}, 17.12$; Co, 14.23; found: C, 40.54; H, 5.80; N, 6.72;
Cl, 17.11; Co, 14.12 , yield: $73 \%$. M.p. $359^{\circ}$ C. Anal. calc. for $\left[\mathrm{Cu}_{2}(\mathrm{o}-\mathrm{tol})_{2}\left(\mathrm{H}_{2} \mathrm{O}\right)_{8}\right] \mathrm{Cl}_{4}: \mathrm{C}, 40.15 ; \mathrm{H}, 5.78 ; \mathrm{N}, 6.69 ; \mathrm{Cl}$, 16.93; $\mathrm{Cu}, 15.17$; found: C, 40.09; $\mathrm{H}, 5.70 ; \mathrm{N}, 6.61 ; \mathrm{Cl}$, 16.88; $\mathrm{Cu}, 15.03$, yield: $79 \%$. M.p. $368^{\circ} \mathrm{C}$.

The $\mathrm{NiO}, \mathrm{Co}_{3} \mathrm{O}_{4}$, and $\mathrm{CuO}$ nanoparticles were synthesized by the thermal decomposition of $\left[\mathrm{Ni}_{2}(\mathrm{o}-\mathrm{tol})_{2}\left(\mathrm{H}_{2} \mathrm{O}\right)_{8}\right]$ $\mathrm{Cl}_{4},\left[\mathrm{Co}_{2}(\mathrm{o} \text {-tol })_{2}\left(\mathrm{H}_{2} \mathrm{O}\right)_{8}\right] \mathrm{Cl}_{4}$, and $\left[\mathrm{Cu}_{2}(\mathrm{o} \text {-tol })_{2}\left(\mathrm{H}_{2} \mathrm{O}\right)_{8}\right] \mathrm{Cl}_{4}$ complexes, respectively as a precursor. The resulting metal-complex in solid-state was calcinated at $\sim 600^{\circ} \mathrm{C}$ for three hours and was then cooled to room temperature (Scheme 1). The color solid powders were washed with methanol at least three times to remove any impurities and dried at $100^{\circ} \mathrm{C}$.

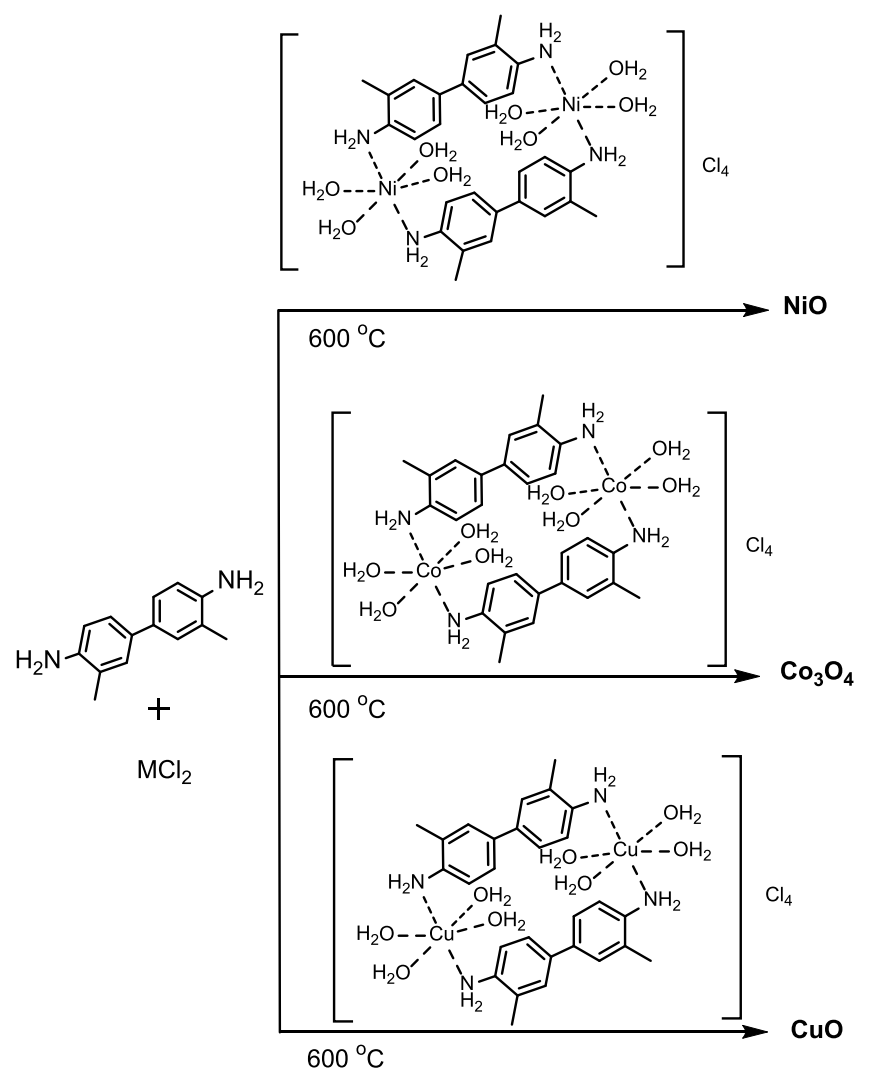

Scheme 1. Thermal decomposition route of synthesis $\mathrm{NiO}, \mathrm{Co}_{3} \mathrm{O}_{4}$, and $\mathrm{CuO}$ by using $\left[\mathrm{M}_{2}(\mathrm{O}-\text { tol })_{2}\left(\mathrm{H}_{2} \mathrm{O}\right)_{8}\right] \mathrm{Cl}_{4}$ precursors

\section{RESULTS AND DISCUSSION}

\section{Interpretations of $\left[\mathrm{M}_{2}(\mathrm{o}-\mathrm{tol})_{2}\left(\mathrm{H}_{2} \mathrm{O}\right)_{8}\right] \mathrm{Cl}_{4}$ precursors}

\section{Analytical and molar conductance data}

The $\left[\mathrm{M}_{2}(\mathrm{o} \text {-tol })_{2}\left(\mathrm{H}_{2} \mathrm{O}\right)_{8}\right] \mathrm{Cl}_{4}$ complexes of nickel, cobalt, and copper (II) metal ions were prepared by heating together methanol/distilled $\mathrm{H}_{2} \mathrm{O}$ solutions of the appropriate ligand and metal chlorides with 1:1 molar ratio. All the prepared complexes are stable at room temperature. The prepared complexes are insoluble in methanol, ethanol, benzene, and acetonitrile, but soluble in DMSO and DMF. The analytical data (carbon, hydrogen, nitrogen, chloride, and metal ions percentages) are presented as mentioned in the experimental section. The molar conductance values of the complexes of $\left(10^{-3} \mathrm{M}\right.$ solution in DMSO) are found to be in the range of 180-225 $\mathrm{ohm}^{-1}$ $\mathrm{cm}^{2} \mathrm{~mol}^{-1}$. These high values indicate that the complexes are ionic with an electrolytic nature ${ }^{\mathbf{1 5}}$. 


\section{Infrared spectra}

By comparison between the spectra of both nickel, cobalt, copper(II) complexes (Fig. 1) and the data of o-tol ligand have been studied and assigned in Table 1 . In the case of o-tol free ligand, the distinguish stretching vibration bands of $v(\mathrm{~N}-\mathrm{H})$ of $\mathrm{NH}_{2}$ group and some of stretching vibrations of $v(\mathrm{C}-\mathrm{H})$ aromatic rings are exhibited at $3475,3412,3375,3338,3213,3019 \mathrm{~cm}^{-1} \mathbf{3 1}$. It is found that the frequencies of $-\mathrm{NH}_{2}$ groups are shifted to a lower wavenumber at the range $3466-3337 \mathrm{~cm}^{-1}$, which indicates that the interactions placed among the nitrogen of $-\mathrm{NH}_{2}$. To place greater emphasis on the interactions between the metal ions and o-tol ligand, the $2000-1000 \mathrm{~cm}^{-1}$ region was investigated. This region contains the bending vibration motions of $-\mathrm{NH}_{2}$ group $\mathrm{\delta NH}_{2}$ which is influenced by complexation and shifted to lower wavenumbers and consequently, the intensity was distorted. Peaks above $3400 \mathrm{~cm}^{-1}$ in the $\mathrm{Co}(\mathrm{II}), \mathrm{Ni}$ (II) and $\mathrm{Cu}$ (II) complexes, indicated the presence of coordinated water ${ }^{31}$. The conforming coordination evidence is also displayed by the presence of new bands in the spectra of all the complexes that occur in the range of 585-508 $\mathrm{cm}^{-1}$ and $443-404 \mathrm{~cm}^{-1}$ are the characteristic bands of stretching vibrations $v(\mathrm{M}-\mathrm{O})$ and $v(\mathrm{M}-\mathrm{N})$ respectively ${ }^{31}$ that are disappeared in the free ligand spectrum.

\section{UV-Vis spectra and magnetic susceptibility}

The electronic spectrum of copper(II) o-tol complex has three electronic absorption bands at 12422, 17007 and $20747 \mathrm{~cm}^{-1}$ due to ${ }^{2} \mathrm{~B}_{1 \mathrm{~g}} \rightarrow{ }^{2} \mathrm{~B}_{2 \mathrm{~g}},{ }^{2} \mathrm{~B}_{1 \mathrm{~g}} \rightarrow{ }^{2} \mathrm{~A}_{2 \mathrm{~g}}$ and ${ }^{2} \mathrm{~B}_{1 \mathrm{~g}} \rightarrow{ }^{2} \mathrm{E}_{1 \mathrm{~g}}$ transitions respectively, which confirmed that $\mathrm{Cu}$ (II) complex has a distorted octahedral geometry ${ }^{32}$. The electronic spectrum of the cobalt(II) complex has three absorption bands at $10965 \mathrm{~cm}^{-1}, 17544 \mathrm{~cm}^{-1}$ and $21505 \mathrm{~cm}^{-1}$ assigned to ${ }^{4} \mathrm{~T}_{1 \mathrm{~g}}(\mathrm{~F}) \rightarrow{ }^{4} \mathrm{~T}_{2 \mathrm{~g}}(\mathrm{~F}),{ }^{4} \mathrm{~T}_{1 \mathrm{~g}}(\mathrm{~F}) \rightarrow{ }^{4} \mathrm{~A}_{2 \mathrm{~g}}(\mathrm{~F})$ and ${ }^{4} \mathrm{~T}_{1 \mathrm{~g}}(\mathrm{~F}) \rightarrow{ }^{4} \mathrm{~T}_{2 \mathrm{~g}}(\mathrm{P})$ electronic transitions respectively, due to octahedral geometry structure ${ }^{33}$. The absorption spectrum of nickel(II) complex included a three electronic bands at $27397 \mathrm{~cm}^{-1}, 16287 \mathrm{~cm}^{-1}$, and 10288 $\mathrm{cm}^{-1}$ assigned to ${ }^{3} \mathrm{~A}_{2 \mathrm{~g}}(\mathrm{~F}) \rightarrow{ }^{3} \mathrm{~T}_{2 \mathrm{~g}}(\mathrm{~F}),{ }^{3} \mathrm{~A}_{2 \mathrm{~g}}(\mathrm{~F}) \rightarrow{ }^{3} \mathrm{~T}_{1 \mathrm{~g}}(\mathrm{~F})$, and ${ }^{3} \mathrm{~A}_{2 \mathrm{~g}}(\mathrm{~F}) \rightarrow{ }^{3} \mathrm{~T}_{2 \mathrm{~g}}(\mathrm{P})$ transitions respectively, these transitions agreement with octahedral geometry. The magnetic moment of the copper(II) complex $(1.81 \mathrm{BM})$ is matched with the octahedral geometry. The magnetic moment value for the nickel (II) complex is $3.10 \mathrm{BM}$ due to the octahedral environment around Ni(II) metal ion. Besides this, the magnetic moment of the cobalt (II) complex is 4.64 BM which consistent with octahedral geometry ${ }^{33}$.

Interpretations of prepared nickel, cobalt, and copper oxides

Nickel, cobalt, and copper oxides nanoparticles have been synthesized via thermal decomposition of a new precursor $\left[\mathrm{M}_{2}(\mathrm{o}-\text { tol })_{2}\left(\mathrm{H}_{2} \mathrm{O}\right)_{8}\right] \mathrm{Cl}_{4}\left(\mathrm{M}=\mathrm{Cu}^{2+}, \mathrm{Co}^{2+}, \mathrm{Ni}^{2+}\right)$ at $\sim 600^{\circ} \mathrm{C}$. The products were characterized by FT-IR, $\mathrm{XRD}$, and TEM.

\section{Characterizations of $\mathrm{NiO}$ oxide}

Figure 2 illustrated the X-ray diffraction patterns for the $\mathrm{NiO}$ nanoparticles. Two very sharp significant diffraction peaks were detected at $2 \theta=37.3^{\circ}$, and $44.4^{\circ}$ assigned to (111) and (200) crystalline planes. The XRD spectrum indicates the face-centered cubic lattice structure with a high degree of crystallinity concerning the prepared NiO NPs. The average crystallite size (D) of $\mathrm{NiO}$ is estimated based on Debye-Scherrer formulas ${ }^{\mathbf{3 4}}$; $\mathrm{D}=\mathrm{k} \lambda \beta \cos \theta$, where $\beta=$ FWHM (full width at half maximum), $\theta$ is the diffraction angle corresponding to maximum intensity peak in XRD pattern (200), $\mathrm{k}$ is an

Table 1. Infrared frequencies/ $\mathrm{cm}^{-1}$ and tentative assignments of o-tol and its complexes

\begin{tabular}{|c|c|c|c|c|}
\hline O-tol & $\mathrm{Ni}(\mathrm{II})$ complex & Co(II) complex & $\mathrm{Cu}(\mathrm{II})$ complex & Assignments \\
\hline $\begin{array}{r}3475 \\
34123375 \\
3338\end{array}$ & 3357 & $\begin{array}{l}3551 \\
3466 \\
3408 \\
3370 \\
3337\end{array}$ & $\begin{array}{l}3448 \\
3353\end{array}$ & $\begin{array}{l}\mathrm{v}(\mathrm{O}-\mathrm{H}) ; \mathrm{H}_{2} \mathrm{O} \\
\mathrm{v}(\mathrm{N}-\mathrm{H}) ; \mathrm{NH}_{2}\end{array}$ \\
\hline 32133019 & 3210 & $\begin{array}{l}3239 \\
3013\end{array}$ & $\begin{array}{l}3220 \\
3019\end{array}$ & $\mathrm{v}(\mathrm{C}-\mathrm{H})$; aromatic rings \\
\hline $\begin{array}{r}298229402898 \\
2856\end{array}$ & 2980 & $\begin{array}{l}2976 \\
2930 \\
2855 \\
\end{array}$ & $\begin{array}{l}2916 \\
2855\end{array}$ & $\begin{array}{l}\mathrm{v}_{\mathrm{s}}(\mathrm{C}-\mathrm{H}) ; \mathrm{CH}_{3} \\
\mathrm{v}_{\mathrm{as}}(\mathrm{C}-\mathrm{H}) ; \mathrm{CH}_{3}\end{array}$ \\
\hline $\begin{array}{r}187016251574 \\
15201489\end{array}$ & $\begin{array}{l}1620 \\
1489\end{array}$ & $\begin{array}{l}1621 \\
1488\end{array}$ & $\begin{array}{l}1620 \\
1511 \\
1482\end{array}$ & $\begin{array}{l}\text { Overtone of } \delta(\mathrm{CH}) \\
\mathrm{v}(\mathrm{C}=\mathrm{C}) \\
\delta\left(\mathrm{NH}_{2}\right) \\
\text { Ring breathing bands }\end{array}$ \\
\hline $\begin{array}{r}145813841321 \\
129512691154 \\
10651039\end{array}$ & $\begin{array}{l}1382 \\
1272 \\
1243 \\
1202 \\
1161 \\
1094 \\
1027 \\
\end{array}$ & $\begin{array}{l}1450 \\
1378 \\
1312 \\
1261 \\
1194 \\
1148 \\
1054 \\
\end{array}$ & $\begin{array}{l}1421 \\
1379 \\
1312 \\
1158 \\
1042\end{array}$ & $\begin{array}{l}\delta_{\mathrm{as}}\left(\mathrm{CH}_{3}\right)+\delta_{\mathrm{s}}\left(\mathrm{CH}_{3}\right) \\
\mathrm{v}(\mathrm{C}-\mathrm{C})+\mathrm{v}(\mathrm{C}-\mathrm{N}) \\
\text { In-plane bending }\end{array}$ \\
\hline $\begin{array}{r}986 \\
944902887 \\
855829777735\end{array}$ & $\begin{array}{l}866 \\
803 \\
755\end{array}$ & $\begin{array}{l}985 \\
941 \\
881 \\
823 \\
734 \\
\end{array}$ & $\begin{array}{l}993 \\
941 \\
876 \\
814\end{array}$ & $\begin{array}{l}(\mathrm{C}-\mathrm{H}) \text { bend } \\
\text { Aromatic rings vibrations }\end{array}$ \\
\hline $\begin{array}{r}682661609583 \\
525425\end{array}$ & 717 & $\begin{array}{l}682 \\
653 \\
607 \\
\end{array}$ & $\begin{array}{l}671 \\
636 \\
589 \\
\end{array}$ & $\begin{array}{l}\text { Aromatic rings vibrations of ortho substituted } \\
\text { Skeletal vibrations }\end{array}$ \\
\hline- & $\begin{array}{l}585 \\
522 \\
\end{array}$ & $\begin{array}{l}574 \\
519 \\
\end{array}$ & 508 & $\mathrm{v}(\mathrm{M}-\mathrm{O})$ \\
\hline- & $\begin{array}{l}443 \\
404 \\
\end{array}$ & 442 & 436 & $v(M-N)$ \\
\hline
\end{tabular}


a)

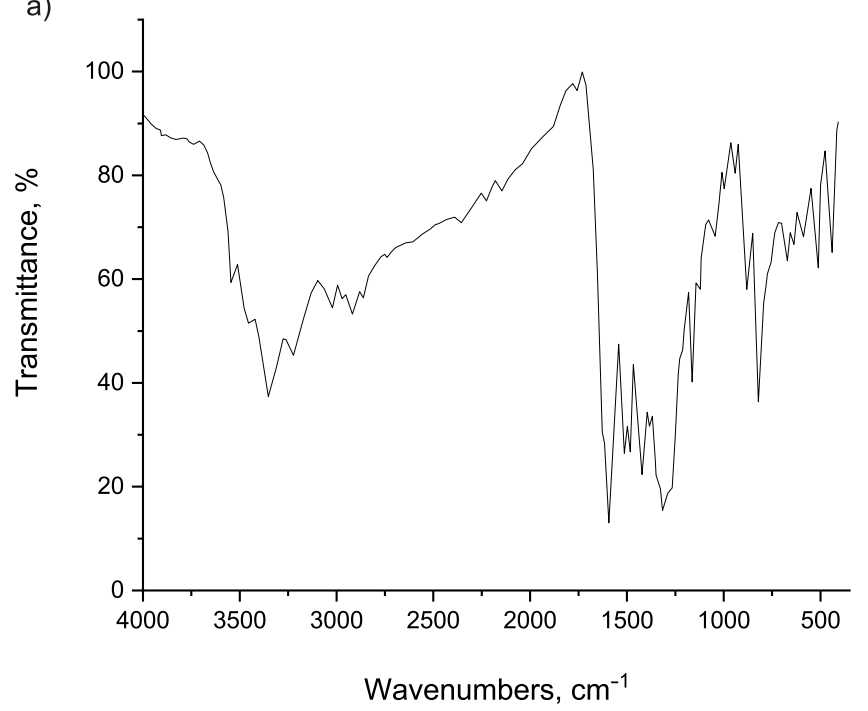

b)

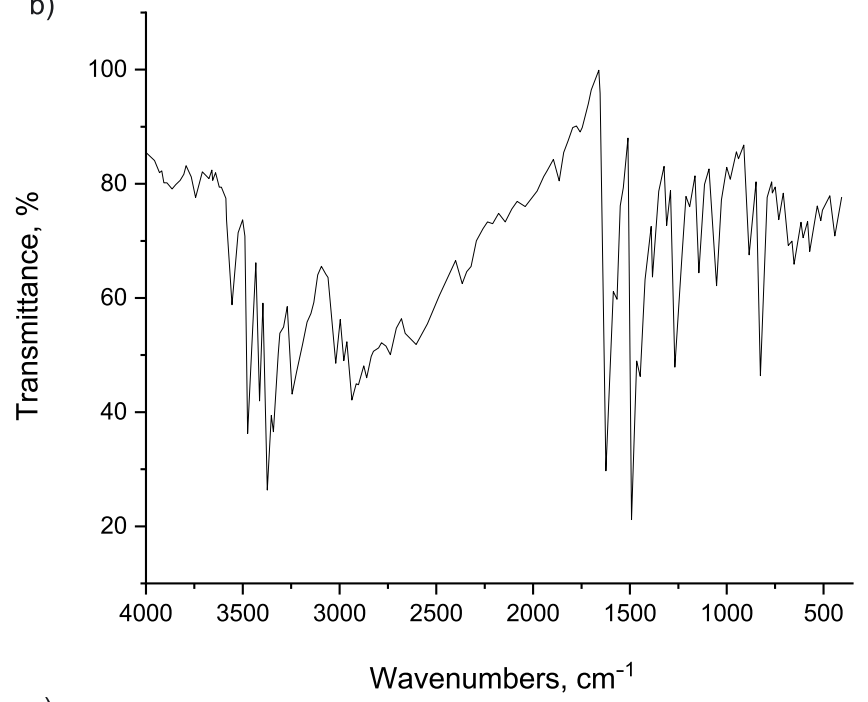

c)

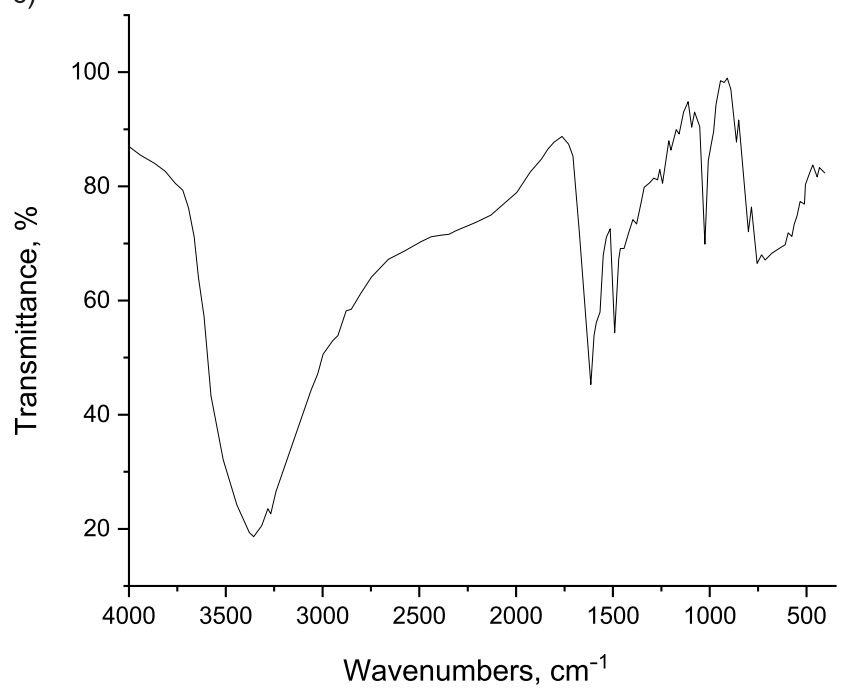

Figure 1. FT IR spectra of a-Cu(II), b-Co(II), and c-Ni(II) o-tol complexes

empirical constant equal to 0.9. Figure 3 a reveals the size, shape, and morphology of the prepared NiO NPs checked by TEM image. The average crystallite size is found to be $9-12 \mathrm{~nm}$, moreover, the figure confirms the spherical shape of NiO NPs with slight agglomeration. The spherical shape offers a good contact area, which is recommended for biosensing applications ${ }^{35}$. The crystallinity index $\left(I_{\text {crys }}\right)$ assigns the mono-crystallinity or poly-crystallinity of the nanoparticles if its value is ap-

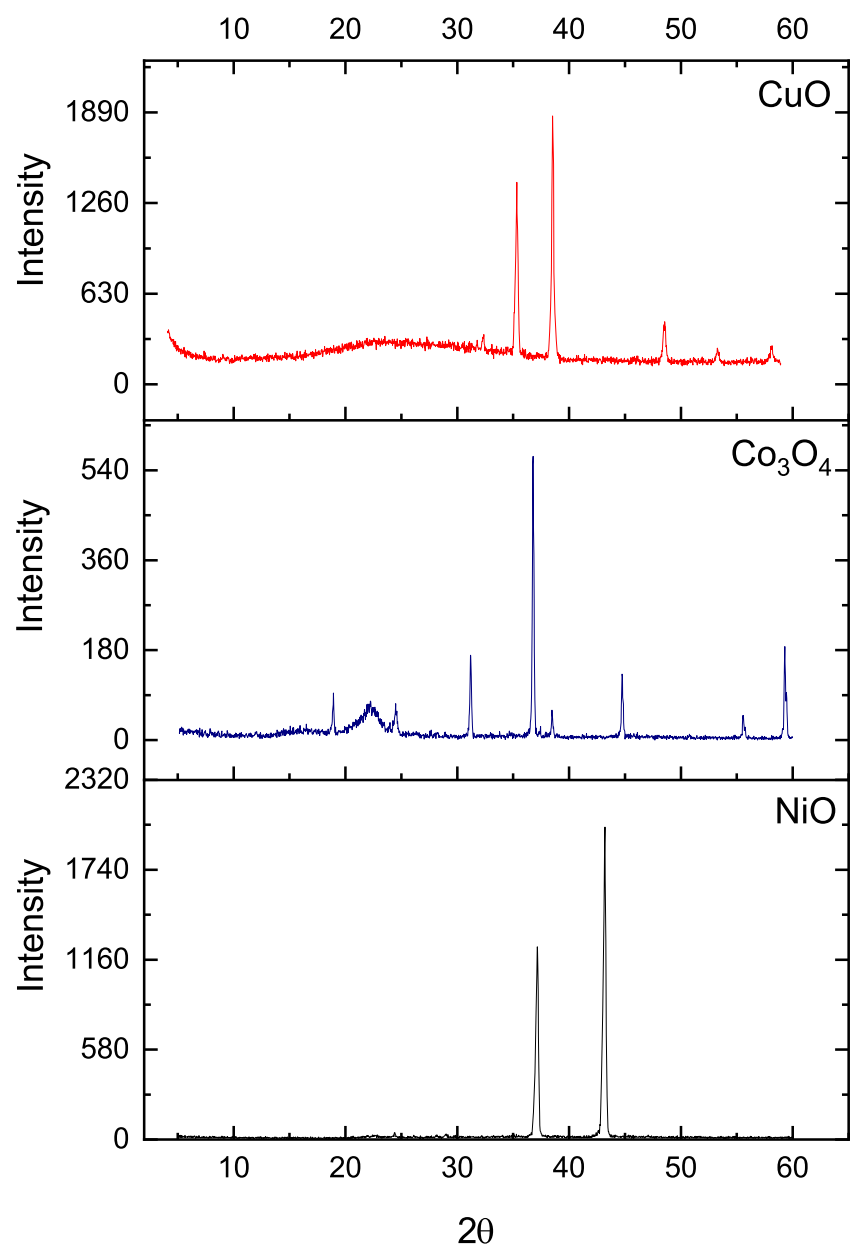

Figure 2. $\mathrm{XRD}$ diffraction patterns of $\mathrm{NiO}, \mathrm{Co}_{3} \mathrm{O}_{4}$, and $\mathrm{CuO}$ oxides

proaching or exceeding one, respectively. It is evaluated using the following equation ${ }^{36}: I_{\text {crys }}=D(T E M) D(X R D)$. The crystallinity index is equal to 0.34 , suggesting the mono-crystallinity of $\mathrm{NiO}$ nanoparticles. Figure 4 represents the FT IR spectrum of the prepared NiO NPs. The spectrum demonstrates a significant peak at $466 \mathrm{~cm}^{-1}$ which is related to the vibrational mode of Ni-O bond. The weak broad peaks occur at $\sim 1630 \mathrm{~cm}^{-1}$ and 3400 $\mathrm{cm}^{-1}$ are assigned to $\mathrm{H}-\mathrm{O}-\mathrm{H}$ bending vibrations mode and $\mathrm{O}-\mathrm{H}$ stretching vibrations bond of crystalline water molecules as moisture on the surface of the prepared $\mathrm{NiO}$ oxide respectively ${ }^{\mathbf{3 1}}$. Elemental analysis was performed to evaluate the elemental composition of the $\mathrm{NiO}$ NPs using EDX spectroscopy. The EDX spectrum of the NiO NPs exhibits distinguish peaks corresponding to $\mathrm{Ni}$ and $\mathrm{O}$, as shown in Figure 5.

\section{Characterizations of $\mathrm{Co}_{3} \mathrm{O}_{4}$ oxide}

The XRD pattern of the prepared $\mathrm{Co}_{3} \mathrm{O}_{4}$ in Figure 2, exhibits some diffraction peaks with $2 \theta$ values at $18.91^{\circ}$, $31.27^{\circ}, 36.75^{\circ}, 38.43^{\circ}, 44.76^{\circ}, 55.57^{\circ}$, and $59.22^{\circ}$. These diffraction peaks can be indexed to the crystalline cubic phase $\mathrm{Co}_{3} \mathrm{O}_{4}$ with a space group of $\mathrm{Fd} 3 \mathrm{~m}$, which agrees with the reported values (JCPDS Card No. 76-1802) ${ }^{\mathbf{3 7}}$. This result confirms that the $\mathrm{Co}_{3} \mathrm{O}_{4}$ phase started to appear at $600^{\circ} \mathrm{C}$, as indicated by the FT-IR result (Figure 4). No impurity diffraction peaks were detected in the patterns, indicating that the product is of high purity. Furthermore, the diffraction peaks are markedly sharpness due to the small size effect of the particles. The average sizes of the $\mathrm{Co}_{3} \mathrm{O}_{4}$ particles were calculated 
a)

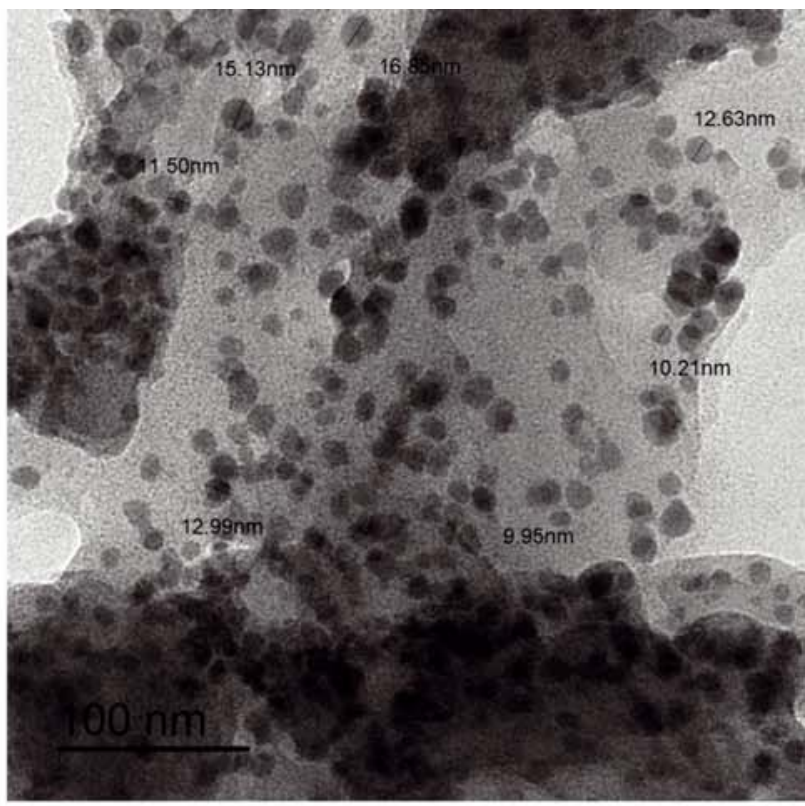

b)

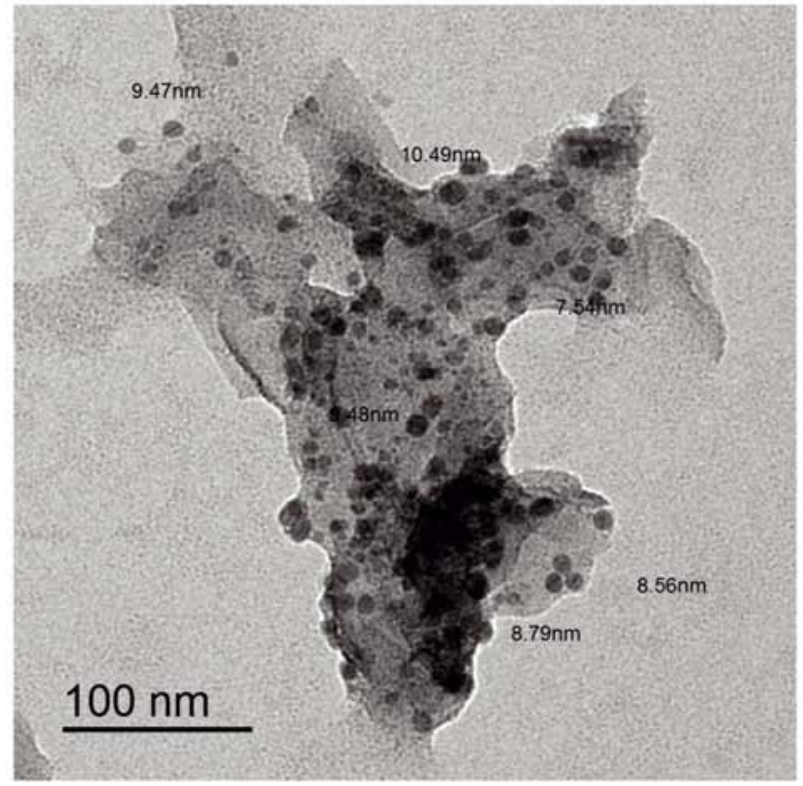

c)

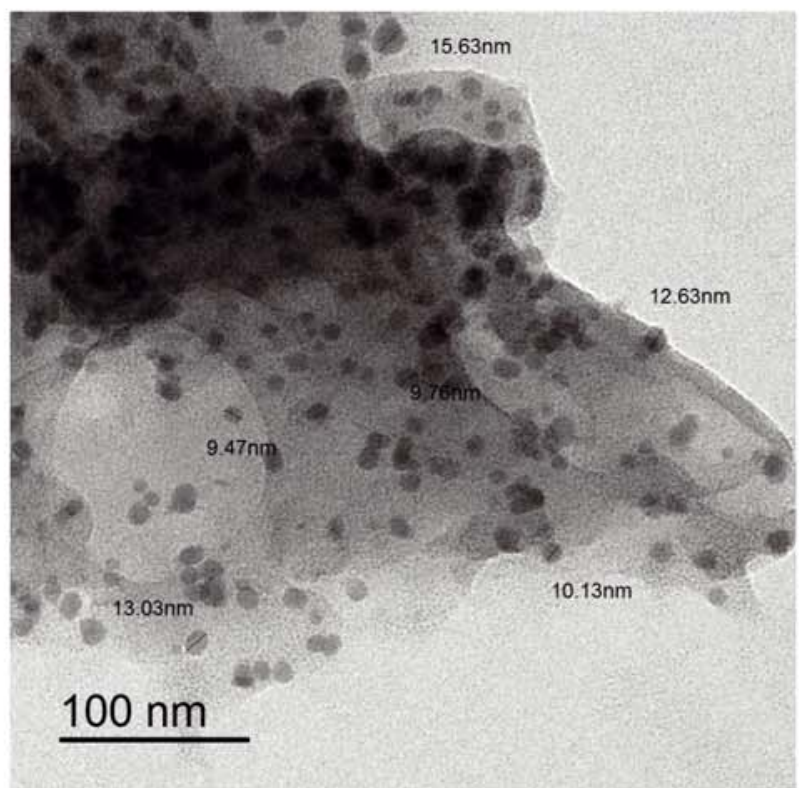

Figure 3. TEM images of a-NiO, b- $\mathrm{Co}_{3} \mathrm{O}_{4}$, and c-CuO oxides

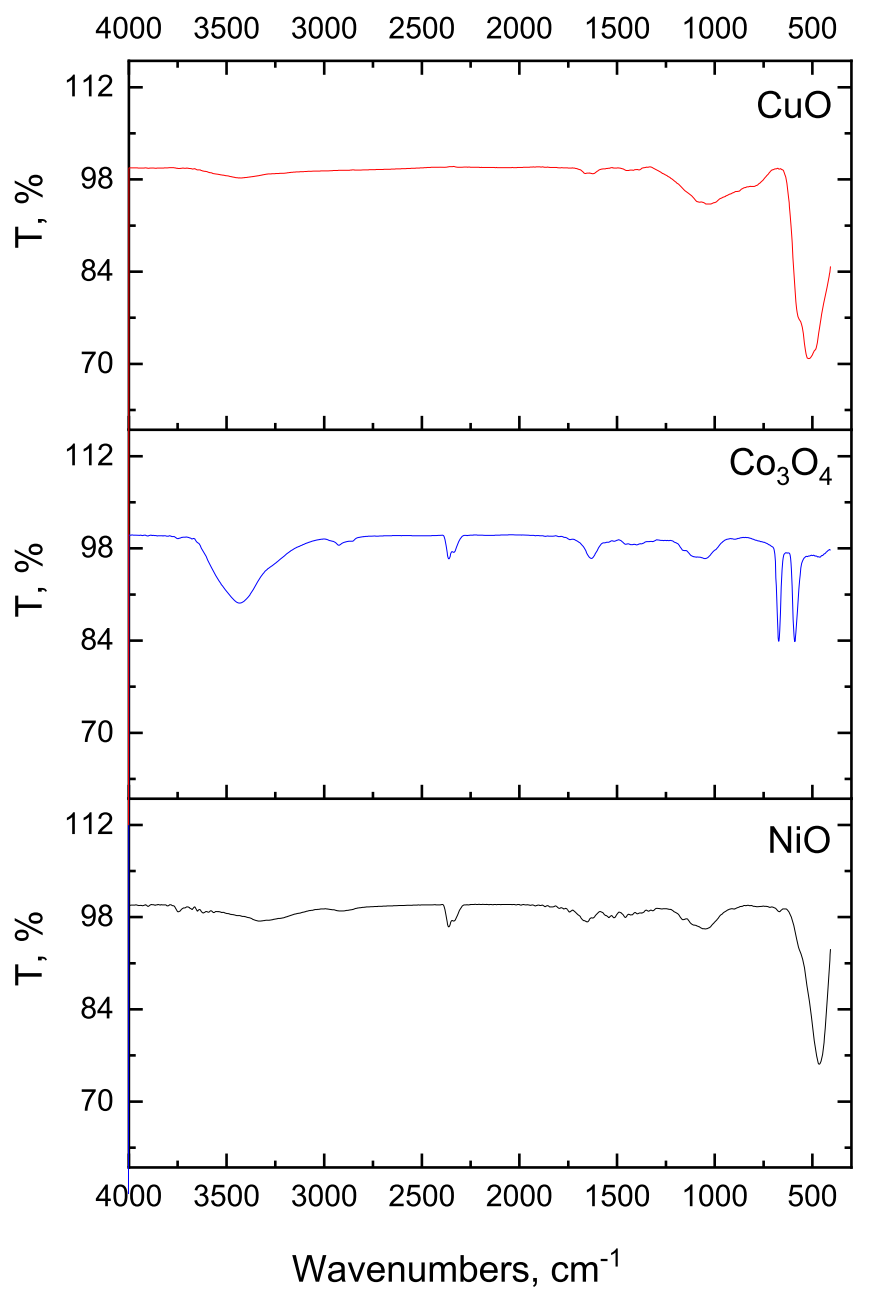

Figure 4. FT IR spectra of $\mathrm{NiO}, \mathrm{Co}_{3} \mathrm{O}_{4}$, and $\mathrm{CuO}$ oxides

by the Debye-Scherrer equation ${ }^{34}$. The average size of the $\mathrm{Co}_{3} \mathrm{O}_{4}$ nanoparticles calculated using the most intense peak (311) at $2 \theta=36.75^{\circ}$ is approximately $12 \mathrm{~nm}$. The TEM image and size distribution of the prepared $\mathrm{Co}_{3} \mathrm{O}_{4}$ NPs are shown in Figure 3. It can be seen from this Figure, that the nanoparticles show approximately black spots spherical morphologies with a uniform size. It is also can find from this figure that the morphology of the particles is almost homogeneous. The diameter sizes of the prepared $\mathrm{Co}_{3} \mathrm{O}_{4}$ NPs are approximately in the range of 8 to $10 \mathrm{~nm}$ with a narrow size distribution. The average particle size is $10 \mathrm{~nm}$, which agrees with the result calculated for the half-width of diffraction peaks using the Scherrer's formula, allowing for experimental error. The FT-IR spectrum of the prepared $\mathrm{Co}_{3} \mathrm{O}_{4}$ has two strong bands of the spinel-type $\mathrm{Co}_{3} \mathrm{O}_{4}$ structure at about 672 and $590 \mathrm{~cm}^{-1}$ are observed. The former band is characteristic of $\mathrm{Co}^{3+}-\mathrm{O}$ vibration in an octahedral site, and the latter one is attributable to the $\mathrm{Co}^{2+}-\mathrm{O}$ vibration in a tetrahedral site of the $\mathrm{Co}_{3} \mathrm{O}_{4}$ lattice ${ }^{37,38}$. The chemical purity and stoichiometry of the product were also examined by EDX analysis. Figure 5 shows the EDX spectrum of the $\mathrm{Co}_{3} \mathrm{O}_{4}$ nanoparticles prepared by the decomposition of $\left[\mathrm{Co}_{2}(\mathrm{o}-\mathrm{tol})_{2}\left(\mathrm{H}_{2} \mathrm{O}\right)_{8}\right] \mathrm{Cl}_{4}$ at $600^{\circ} \mathrm{C}$. Only oxygen and cobalt elements existed in the product. The atomic percentages of $\mathrm{Co}$ and $\mathrm{O}$ were found to be $71.02 \%$ and $28.98 \%$, respectively. The carbon peak at about $0.277 \mathrm{keV}$ corresponds to the TEM holding grid. No other elements can be detected, indicating the high purity of the $\mathrm{Co}_{3} \mathrm{O}_{4}$ nanoparticles. 


\section{Characterizations of $\mathrm{CuO}$ oxide}

For XRD patterns of the $\mathrm{CuO}$ nanoparticles, all peaks can be confirmed to be the monoclinic phase of $\mathrm{CuO}$ (JCPDS no. 48-1548) ${ }^{35}$ as shown in Figure 2. The smaller size of $\mathrm{CuO}$ nanoparticles can be predicted consistently with the broadening diffraction peaks of XRD patterns. Moreover, the crystallite size based on the broadening diffraction peaks was approximately estimated from the corresponding X-ray spectral peak employing the Debye-Scherrer's formula ${ }^{34}$. The calculated value was estimated to be $15 \mathrm{~nm}$. Figure $3 \mathrm{c}$ showed the morphology of highly crystalline $\mathrm{CuO}$ nanoparticles from TEM analysis. Nevertheless, the accurate sizes and morphology of the nanoparticles can be estimated from the TEM analysis, TEM images can reveal the internal structure and more accurate measurement of particle size (9-15 nm) and morphology. FTIR spectrum revealed vibration of the $\mathrm{CuO}$ band at $524 \mathrm{~cm}^{-1}$ (Fig. 4). The corresponding EDX (Fig. 5) spectrum can also confirm the presence of $\mathrm{Cu}$ and $\mathrm{O}$ elements in the sample. The spherical $\mathrm{CuO}$ nanoparticles are evaluated by EDX quantitative analysis software (Oxford Instrument) and found to have 55.62
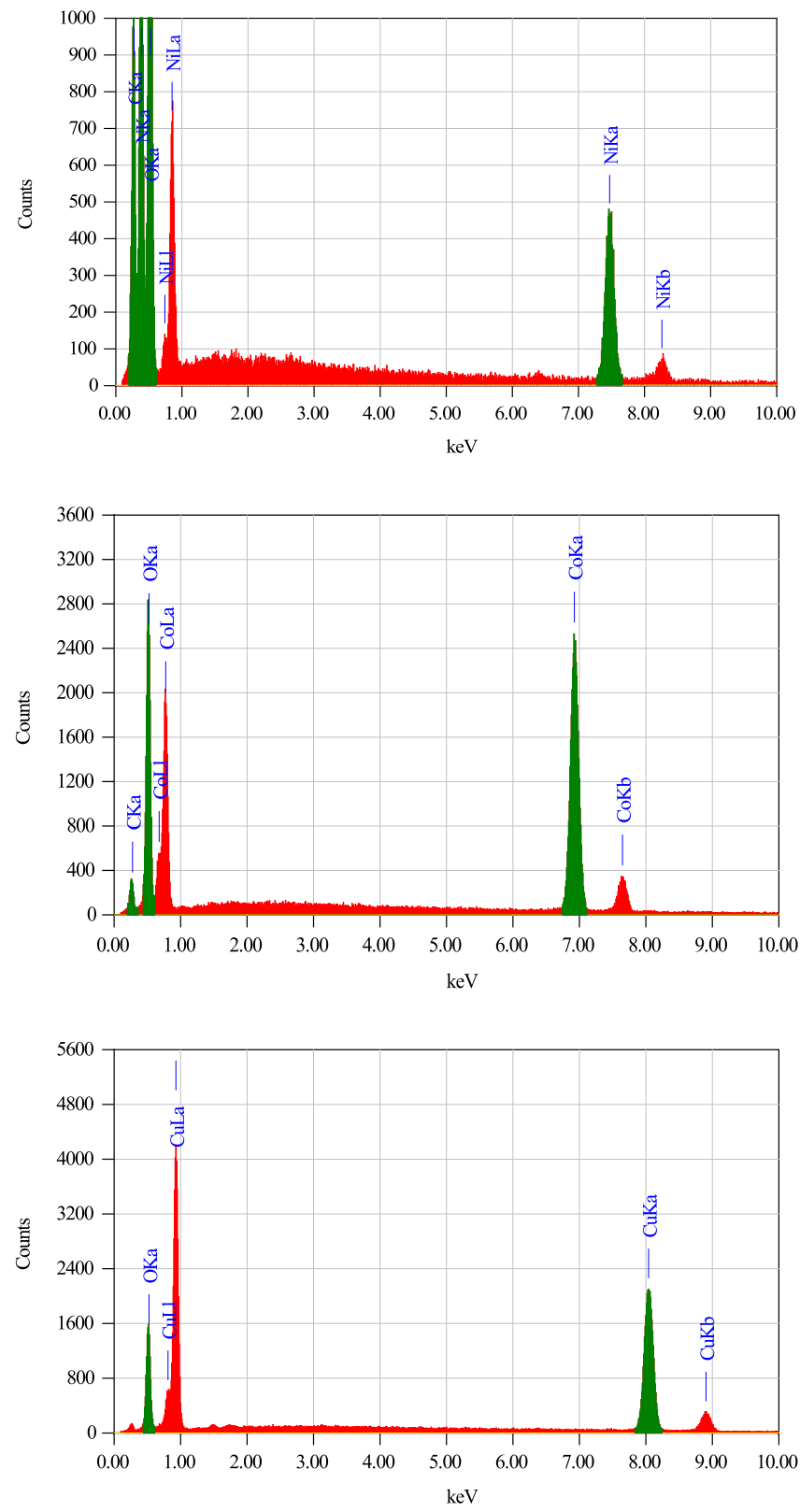

Figure 5. EDX spectra of $\mathrm{NiO}, \mathrm{Co}_{3} \mathrm{O}_{4}$, and $\mathrm{CuO}$ oxides at $\%$ of $\mathrm{Cu}$ and 44.38 at\% of $\mathrm{O}$. If it is in atomic \%, theoretically the $\mathrm{Cu}$ will be $50 \%$ and $\mathrm{O}$ will be $50 \%$. But in the experimental found 55.62 at $\%$ of $\mathrm{Cu}$ and 44.38 at $\%$ of O. Because of the EDX, analysis techniques can select only one area. Thus, the amount of $\mathrm{Cu}$ and $\mathrm{O}$ in a different area may be different values, so in the dispersion of $\mathrm{CuO}$ nanoparticles were found into a high and poor dispersion, respectively.

\section{ACKNOWLEDGMENT}

Taif University Researches Supporting Project number (TURSP-2020/01), Taif University, Taif, Saudi Arabia.

\section{LITERATURE CITED}

1. Noller, C.R. (1960). Textbook of Organic Chemistry, Springer Verlag.

2. Hunger, K. \& Herbst, W. (2012). "Pigments, Organic" in Ullmann's Encyclopedia of Industrial Chemistry, Wiley-VCH, Weinheim, DOI: 10.1002/14356007.a20_371.

3. Ahangaran, F. \& Navarchian, A.H. (2020). Recent advances in chemical surface modification of metal oxide nanoparticles with silane coupling agents: A review. Adv. Colloid. Interface Sci. 286. 102298. DOI: 10.1016/j.cis.2020.102298.

4. Rahal, H.T., Awad, R., Abdel Gaber, A.M. \& Bakeer, D. (2017). Synthesis, characterization, and magnetic properties of pure and EDTA-capped $\mathrm{NiO}$ nanosized particles. J. Nanomaterials, 2017, 9. DOI: 10.1155/2017/7460323.

5. Al Boukhari, J., Zeidan, L., Khalaf, A. \& Awad, R. (2019). Synthesis, characterization, optical and magnetic properties of pure and $\mathrm{Mn}, \mathrm{Fe}$ and $\mathrm{Zn}$ doped $\mathrm{NiO}$ nanoparticles. J. Chem. Phys., 516, 116-124. DOI:10.1016/j.chemphys.2018.07.046.

6. Meng, F., Shi, W., Sun, Y., Zhu, X., Wu, G., Ruan, C., Liu, X. \& Ge, D. (2013). Nonenzymatic biosensor based on $\mathrm{CuxO}$ nanoparticles deposited on polypyrrole nanowires for improving detectionrange. J. Biosens. Bioelectr., 42, 141-147. DOI: $10.1016 /$ j.bios.2012.10.051.

7. Gao, Q., Zeng, W. \& Miao, R. (2016). Synthesis of multifarious hierarchical flower-like $\mathrm{NiO}$ and their gas-sensing properties. J. Mat. Sci. Mat. Electron., 27(9), 9410-9416. DOI: 10.1007/s10854-016-4986-3.

8. Koh, I. \& Josephson, L. (2009). Magnetic nanoparticle sensors. J. Sensors, 9(10), 8130-8145. DOI:10.3390/s91008130.

9. Nur, S., Yazid, A.M., Md Isa, I., Abu Bakar, S., Hashim, N. \& Ab Ghani, S. (2014). A review of glucose biosensors based on graphene/metal oxide nanomaterials. Analyt. Lett., 47(11), 1821-1834. DOI: 10.1080/00032719.2014.888731.

10. Wu, R., Wu, J., Yu, M., Tsai, T. \& Yeh, C. (2008). Applications of Semiconducting Metal Oxides Gas Sensors. Sens. Actu. B: Chem., 131, 306-312. DOI: 10.1016/j.snb.2007.11.033.

11. Mate, V.R., Shirai, M., \& Rode, C.V. (2013). Heterogeneous $\mathrm{Co} 3 \mathrm{O} 4$ catalyst for selective oxidation of aqueous veratryl alcohol using molecular oxygen. Catal. Commun., 33, 66-69. DOI: $10.1016 /$ j.catcom.2012.12.015.

12. Maruyama, T., \& Arai, S. (1996). Electrochromic properties of cobalt oxide thin films prepared by chemical vapor deposition. J. Electrochem. Soc., 143, 1383-1386. DOI: 10.1149/1.1836646.

13. Li, Y.G., Tan, B. \& Wu, Y.Y. (2008). Mesoporous $\mathrm{Co} 3 \mathrm{O} 4$ Nanowire Arrays for Lithium Ion Batteries with High Capacity and Rate Capability. Nano Lett., 8, 265-270. DOI: 10.1021/n10725906.

14. Wang, R.M., Liu, C.M., Zhang, H.Z., Chen, C.P., Guo, L., Xu, H.B. \& Yang, S.H. (2004). Porous nanotubes of $\mathrm{Co}_{3} \mathrm{O}_{4}$ : Synthesis, characterization, and magnetic properties. Appl. Phys. Lett., 85, 2080-2082. DOI: 10.1063/1.1789577. 
15. Lou, X., Han, J., Chu, W., Wang, X. \& Cheng, Q. (2007). Synthesis and photocatalytic property of $\mathrm{Co}_{3} \mathrm{O}_{4}$ nanorods. Mater. Sci. Eng., B: 137, 268-271. DOI: 10.1016/j.mseb.2006.12.002.

16. Warang, T., Patel, N., Santini, A., Bazzanella, N., Kale, A. \& Miotello, A. (2012). Pulsed laser deposition of Co3O4 nanoparticles assembled coating: Role of substrate temperature to tailor disordered to crystalline phase and related photocatalytic activity in degradation of methylene blue. Appl. Catal. A: Gen. 423-424, 21-27. DOI: 10.1016/j.apcata.2012.02.037.

17. Sun, H., Ahmad, M. \& Zhu, J. (2013). Morphology-controlled synthesis of $\mathrm{Co} 3 \mathrm{O} 4$ porous nanostructures for the application as lithium-ion battery electrode. Electrochim. Acta, 89, 199-205. DOI: 10.1016/j.electacta.2012.10.116.

18. Lester, E., Aksomaityte, G., Li, J. \& Gomez, S. (2012). Controlled continuous hydrothermal synthesis of cobalt oxide (Co3O4) nanoparticles. Prog. Cryst. Growth Charact. Mater. 58, 3-13. DOI: 10.1016/j.pcrysgrow.2011.10.008.

19. Gardey-Merin, M.C., Palermo, O.M., Belda, R., Fernández de Rapp, M.E., E.Lascalea, G. \& Vázquez, P.G. (2012). Combustion synthesis of $\mathrm{Co} 3 \mathrm{O} 4$ nanoparticles: fuel ratio effect on the physical properties of the resulting powders. Proced. Mater. Sci., 1, 588-593. DOI: 10.1016/j.mspro.2012.06.079.

20. Bhatt, A.S., Bhat, D.K., Tai, C.W. \& Santosh, M.S. (2011). Microwave-assisted synthesis and magnetic studies of cobalt oxide nanoparticles. Mater. Chem. Phys., 125, 347-350. DOI: 10.1016/j.matchemphys.2010.11.003.

21. Baydi, M.E., Poillerat, G., Rehspringer, J.L., Gautier, J.L., Koenig, J.F. \& Chartier, P. (1994). A sol-gel route for the preparation of $\mathrm{Co} 3 \mathrm{O} 4$ catalyst for oxygen electrocatalysis in alkaline medium. J. Solid State Chem., 109, 281-288. DOI: 10.1006/jssc.1994.1105.

22. Kim, D.Y., Ju, S.H., Koo, H.Y., Hong, S.K. \& Kangf, Y.C. (2006). Synthesis of nanosized Co3O4 particles by spray pyrolysis. J. Alloys Compd., 417, 254-258. DOI: 10.1016/j. jallcom.2005.09.013.

23. Kumar, R.V., Diamant, Y. \& Gedanken, A. (2000). Sonochemical synthesis and characterization of nanometer-size transition metal oxides from metal acetates. Chem. Mater., 12, 2301-2305. DOI: 10.1021/cm000166z.

24. Sinko, K., Szabo, G. \& Zrinyi, M. (2011). Liquid-phase synthesis of cobalt oxide nanoparticles. J. Nanosci. Nanotechnol., 11, 1-9. DOI: 10.1166/jnn.2011.3875.

25. Zou, D., Xu, C., Luo, H., Wang, L. \& Ying, T. (2008). Synthesis of $\mathrm{Co} 3 \mathrm{O} 4$ nanoparticles via an ionic liquid-assisted methodology at room temperature. Mater. Lett., 62, 1976-1978. DOI: 10.1016/j.matlet.2007.10.056.
26. Jiang, J. \& Li, L. (2007). Synthesis of sphere-like $\mathrm{Co}_{3} \mathrm{O}_{4}$ nanocrystals via a simple polyol route. Mater. Lett., 6, 4894-4896. DOI: 10.1016/j.matlet.2007.03.067.

27. Fan, S., Liu, X., Li, Y., Yan, E., Wang, C., Liu, J. \& Zhang, Y. (2013). Non-aqueous synthesis of crystalline Co3O4 nanoparticles for lithium-ion batteries. Mater. Lett., 91, 291-293. DOI: 10.1016/j.matlet.2012.10.008.

28. Masoomi, M.Y. \& Morsali, A. (2012). Applications of metal-organic coordination polymers as precursors for preparation of nano-materials. Coord. Chem. Rev., 256, 2921-2943. DOI: 10.1016/j.ccr.2012.05.032.

29. El-Trass, A., Elshamy, H., El-Mehasseb, I. \& El-Kemary, M. (2012). CuO nanoparticles: synthesis, characterization, optical properties and interaction with amino acids. Appl. Sur. Sci., 258(7), 2997-3001. DOI: 10.1016/j.apsusc.2011.11.025.

30. Refat, M.S. (2007). Complexes of uranyl(II), vanadyl(II) and zirconyl(II) with orotic acid "vitamin B13": Synthesis, spectroscopic, thermal studies and antibacterial activity. J. Mol. Struct., 842(1-3), 24-37. DOI: 10.1016/j.molstruc.2006.12.006.

31. Nakamoto, K. (1997). Infrared and Raman Spectra of Inorganic and Coordination Compounds, Wiley, New York.

32. Lever, A.B.P. \& Mantovani, E. (1971). Far-infrared and electronic spectra of some bis(ethylenediamine) and related complexes of copper(II) and the relevance of these data to tetragonal distortion and bond strengths. Inorg. Chem., 10, 817-826. DOI: $10.1021 / \mathrm{ic} 50098 \mathrm{a} 031$.

33. Lever, A.B.P. (1968). Inorganic Electronic Spectroscopy, Elsevier, Amsterdam, (1968).

34. Waseda, Y., Matsubara, E. \& Shinoda, K. (2011). X-Ray Diffraction Crystallography. Verlag, Berlin Heidelberg: Springer. DOI: 10.1007/978-3-642-16635-8.

35. Kolhatkar, A., Jamison, A., Litvinov, D., Willson, R. \& Lee, T. (2013). Tuning the magnetic properties of nanoparticles. Int. J. Mol. Sci., 14(8), 15977-16009. DOI:10.3390/ ijms140815977.

36. Rifaya, M.N., Theivasanthi, T. \& Alagar, M. (2012). Chemical capping synthesis of nickel oxide nanoparticles and their characterizations studies. Nanosc. Nanotechnol., 2(2), 134-138. DOI: 10.5923/j.nn.20120205.01.

37. Farhadi, S., Javanmard, M. \& Nadri, G. (2016). Characterization of cobalt oxide nanoparticles prepared by the thermal decomposition. Acta Chim. Slov., 63, 335-343. DOI: 10.17344/acsi.2016.2305.

38. Tamaekong, N., Liewhiran, C. \& Phanichphant, S. (2014). Synthesis of thermally spherical $\mathrm{CuO}$ nanoparticles. J. Nanomaterials, 2014, Article ID 507978, 5 pages. DOI: $10.1155 / 2014 / 507978$. 